\title{
COMUNICAÇÕES
}

\section{Natural infection of Porophyllum ruderale with a nucleorhabdovirus in Brazil}

Ana Carolina Christino de Negreiros Alves ${ }^{1}$, José Edivaldo Buriolla ${ }^{1}$, Elliot Watanabe Kitajima ${ }^{1}$ and Jorge Alberto Marques Rezende ${ }^{1 *}$

${ }^{1}$ Departamento de Entomologia, Fitopatologia e Zoologia Agrícola, ESALQ, Universidade de São Paulo, 13418-900 Piracicaba, SP, jamrezen@esalq.usp.br

Autor par correspondência: Jorge Alberto Marques Rezende

Data de chegada: 14/08/2007. Aceito para publicação em: 30/06/2008



Figure 1. Leaves of Porophyllum ruderale exhibiting yellow mottling (A), and bacilliform particles (70-80 $\mathrm{nm} \times 300 \mathrm{~nm})$, typical of rhabdoviruses, associated with the nucleus of infected cell (B). Particles detail in the insert.

Porophyllum ruderale (Asteraceae) is an annual ruderal aromatic herb, which can reach $1.3 \mathrm{~m}$ in height and is widely distributed in Brazil. In traditional medicine, a tea made from its leaves is used as an antibacterial and for the treatment of snakebites, stomach ache, wounds and as anti-inflammatory (Lorenzi, H. \& Matos, F.J.A. 2002. Plantas medicinais no Brasil: nativas e exóticas cultivadas, Nova Odessa, São Paulo: Instituto Plantarum). Glands present on leaves of $P$. ruderale produce potent allelo chemicals that repress insect herbivory (Guillet et al., Journal of Ecology 85:647-655, 1997). Plants of this species exhibiting yellow mottling and leaf blade reduction were found in the rural area of Piracicaba County, São Paulo State, Brazil. Preliminary transmission electron microscopy analysis of leaf dip preparations of infected leaves revealed the presence of bacilliform particles (70-80 $\mathrm{nm} \times 300 \mathrm{~nm}$ ), typical of rhabdoviruses. In thin sections these particles were seen associated with the nucleus, suggesting an infection by a nucleorhabdovirus. Extract from infected plants was mechanically inoculated onto leaves of different species. Nicotiana benthamiana, $N$. x edwardsonii, N. glutinosa, P. ruderale, and Sonchus oleraceus were systemically infected and developed yellow mosaic. $N$. benthamiana also showed yellow spots on the inoculated leaves. Chenopodium quinoa, Datura stramonium and Gomphrena globosa developed only chlorotic local lesions on the inoculated leaves. Electron microscopy confirmed the presence of the nucleorhabdovirus in all these susceptible plants. Healthy plants were obtained from 336 seeds harvested from infected $P$. ruderale. The following species did not show symptoms of infection by this virus upon mechanical inoculation: Acanthospermum hispidum, Ageratum conyzoides, Bidens pilosa, Cajanus cajan, Capsicum annuum, Chenopodium amaranticolor, Crotalaria breviflora, C. juncea, $C$. mucronata, C. orchnoleuca, Cucurbita pepo cv. Caserta, Euphorbia hirta, Galinsoga parviflora, Glycine max, Ipomea sp, Solanum slycopersicum, Nicotiana clevelandii, N. tabacum cv Turkish, Passiflora edulis f. flavicarpa, Phaseolus vulgaris, Pterogynes nitens, Rhaphanus sativus, Shorgum bicolor, Zea mays and Zinnia elegans. The known properties of this nucleorhabdovirus resembles that of the Gomphrena virus previously described in Brazil (Kitajima \& Costa, Virology 29:523-539,1966), which might represent an isolate of the Sowthistle yellow net virus. 